\title{
Effect of Dietary Strong lons on Chewing Activity and Milk Production in Lactating Dairy Cows
}

\author{
C. S. Mooney ${ }^{1}$ and M. S. Allen ${ }^{2}$ \\ Department of Animal Science, Michigan State University, East Lansing 48824
}

\begin{abstract}
The objective of this experiment was to determine effects of strong ions on chewing activity and shortterm lactational performance of dairy cows. Forty multiparous Holstein cows were used in a replicated $5 \times 5$ Latin square design with a $2 \times 2$ factorial arrangement of equimolar treatments for cations (sodium and potassium), anions (chloride and bicarbonate), plus a control diet. Periods were $14 \mathrm{~d}$ in length with the last $4 \mathrm{~d}$ for data and sample collection. Diets were formulated to $29 \%$ neutral detergent figer and $17.5 \%$ crude protein. Sodium bicarbonate was included at $1 \%$ of dry matter in one treatment diet, and other treatments (sodium chloride, potassium chloride, and potassium bicarbonate) were added to be equimolar to sodium bicarbonate in their respective diets. Chewing activity was recorded every 5 min for the last $24 \mathrm{~h}$ of each period. Dry matter intake was not affected by treatment (mean $=27.9 \mathrm{~kg} /$ d). Bicarbonate treatments increased yields of milk, milk fat, and fat- and solids-corrected milk compared with chloride treatments, but cation treatments did not affect any measured variable. The 4 ion treatments reduced ruminating time per day when compared with control by decreasing the length of rumination bouts. This effect was not specific to cations or anions suggesting a mechanism related to increased ruminal osmolality.
\end{abstract}

Key words: ruminal buffer, osmolality, rumination

\section{INTRODUCTION}

Sodium is a strong ion and is regulated as the primary extracellular cation (NRC, 2001). It is a constituent of saliva and charge-paired with bicarbonate and hydrogen phosphate to form the 2 major buffers of cattle saliva (Bailey and Balch, 1961). These buffers are important components of a system to regulate hydrogen

\footnotetext{
Received January 5, 2007.

Accepted July 30, 2007.

${ }^{1}$ Current address: William H. Miner Agricultural Research Institute, PO Box 100, Chazy, NY 12921-0100.

${ }^{2}$ Corresponding author: allenm@msu.edu
}

ion concentration in the reticulorumen (RR; Allen, 1997). When buffer flow from saliva is not adequate, the addition of sodium bicarbonate to the diet of lactating dairy cows may be justified (Erdman, 1988).

The ruminal infusion of sodium containing compounds may influence rumination time. Rumination in sheep infused intraruminally with $1.2 \mathrm{~mol}$ of sodium bicarbonate was suspended nearly 10 times longer than controls (444 vs. $48 \mathrm{~min}$; Welch, 1982). In lactating cows, sodium bicarbonate (110 g/dose) infused into the rumen twice per day initially decreased ruminal hydrogen ion concentration, but after several hours, ruminal hydrogen ion concentration increased relative to controls (Hogue et al., 1991). Chewing activity was not reported for this experiment, but decreased rumination is a possible explanation for this delayed increase in ruminal hydrogen ion concentration. Furthermore, sodium salts of VFA (acetate or propionate) infused into the RR at the onset of spontaneous meals $(3 \mathrm{~L}$ of 0.75 $M$ sodium salts of VFA over $5 \mathrm{~min}$ ) decreased rumination time during the 12-h test period compared with their acids (acetic or propionic) and to a sham control (Choi and Allen, 1999). However, in these 3 studies, ruminal infusions may have generated ruminal conditions that are not representative of normal physiological or nutritional conditions.

Inclusion of sodium bicarbonate at 0.6 to $1.0 \%$ of the dietary DM (NRC, 2001) of lactating dairy cow diets is a common industry practice to provide additional ruminal buffering, but the effect of this inclusion in typical diets on the rumination time of lactating dairy cow is not known. Reduction in ruminating time per day by sodium addition to the diet could reduce total daily salivary flow to the RR and, given the fairly constant concentration of buffers in the saliva (Bailey and Balch, 1961), total buffer flow into the RR.

The objectives of this experiment were to determine 1) the specificity of sodium involvement in the regulation of rumination (sodium specific or general osmotic effect), and 2) the extent to which sodium bicarbonate reduces rumination while providing its benefits to milk yield and composition (Erdman, 1988) when included in a typical lactating dairy cow diet at commonly recom- 
mended concentrations. The alternate hypothesis is that dietary sodium addition decreases rumination time per day.

\section{MATERIALS AND METHODS}

Animal procedures were approved by the All University Committee on Animal Use and Care at Michigan State University.

\section{Design}

Forty multiparous Holstein cows $(126 \pm 53$ DIM; mean \pm SD) from the Michigan State University Dairy Cattle Teaching and Research Center were assigned randomly to replicated $5 \times 5$ Latin squares balanced for carryover effects with a $2 \times 2$ factorial arrangement of equimolar treatments for cations (sodium and potassium), anions (chloride and bicarbonate), plus a control diet. Potassium, the primary intracellular cation, was selected to contrast with sodium, the primary extracellular cation, because of its similar charge and osmolality but different physiological role. Chloride was selected to contrast with bicarbonate for similar reasons. Also, all 4 ions are commonly found in diets of lactating dairy cows. Experimental periods were $14 \mathrm{~d}$ with the final $4 \mathrm{~d}$ used for sample and data collection. This design was expected to have the power to detect a 10-min difference in chewing activity, and this difference was the minimum thought to be meaningful given the method of chewing activity measurement and an expected saliva flow and composition.

\section{Treatments}

Experimental diets contained corn silage, alfalfa silage, mixed, mostly alfalfa hay $(57.8,28.7$, and $13.5 \%$ of forage DM, respectively), whole cottonseed, high moisture shelled corn, a premix of protein supplements (soybean meal, distillers grains, and blood meal), a premix of minerals and vitamins, and a premix containing the treatments (Tables 1 and 2). All diets were formulated for $17.5 \%$ dietary CP concentration, $29 \%$ dietary $\mathrm{NDF}$ concentration, and minimum NRC mineral and vitamin requirements (Table 3 ). The control diet provided sodium, potassium, and chloride to meet or exceed requirements and treatments were added as ground rice hulls were removed. Therefore, sodium, potassium, and chloride on treatment diets were either at or in excess of requirements depending upon the specific treatment. All ingredients except the treatment mixes were combined to form a base mix common to all diets. The base mix was combined daily with each treatment mix in a tumble mixer (Roll-A-Mix Mini-Mix, model
690, Sand Mark Corporation, Marshfield, WI) for $3 \mathrm{~min}$ to form the 5 final experimental diets. Trace-mineral salt blocks were not available to cows for the duration of the experiment.

\section{Data And Sample Collection}

Throughout the experiment, cows were housed in tiestalls and fed once daily ( $1030 \mathrm{~h})$ at $110 \%$ of expected intake. The amount of feed offered and refused (orts) was weighed daily for each cow. Samples of all dietary ingredients $(0.5 \mathrm{~kg})$ and orts $(12.5 \%)$ were collected daily during the test phase of each period. Samples were frozen immediately after collection at $-20^{\circ} \mathrm{C}$.

Cows were moved to an exercise lot twice daily ( 0300 and $1300 \mathrm{~h}$ ) prior to milking in a parlor (0430 and $1430 \mathrm{~h}$ ). Milk yield at both milkings was measured and summed for a daily total on d 11 to 14 of each period. These daily totals were averaged for each period. Milk was sampled at each milking on d $11,12,13$, and 14 of each period and analyzed for fat, true protein, lactose, solids-not-fat, MUN, and SCC with midinfrared spectroscopy (AOAC, 2003) by Michigan DHIA (East Lansing). Body weight was measured immediately prior to the start of the first period and following the morning milking on d 14 of each period. Body condition score was determined (Wildman et al., 1982; 5-point scale where $1=$ thin to $5=$ fat) by 2 trained investigators blinded to treatments immediately prior to the start of the first period and on the last day each period. Chewing activity was monitored and recorded by observation every $5 \mathrm{~min}$ for $24 \mathrm{~h}$ on d 14 of each period. Activity was noted as eating, ruminating, drinking, or idle for each cow at each time.

\section{Sample Processing}

Samples were thawed and composited to one sample per cow per period prior to drying. Diet ingredients and orts were dried in a $55^{\circ} \mathrm{C}$ forced-air oven for $72 \mathrm{~h}$, and DM concentration was determined. Forages and whole cottonseed samples were ground with a Wiley mill (1 mm screen; Arthur H. Thomas, Philadelphia, PA). High-moisture shelled corn and all premixes were ground with a Udy Cyclone Sample Mill (2-mm screen; Fort Collins, CO).

\section{Sample Analysis}

Samples were analyzed for DM, ash, CP, starch, and $\mathrm{NDF}$. Ash concentration was determined after $5 \mathrm{~h}$ oxidation at $500^{\circ} \mathrm{C}$ in a muffle furnace. Crude protein was analyzed according to Hach et al. (1987). Starch corrected for free glucose was measured by an enzymatic 
Table 1. Nutrient composition of ingredients used to formulate experimental diets (\% of dietary DM)

\begin{tabular}{|c|c|c|c|c|c|c|c|c|c|c|c|c|}
\hline \multirow[b]{2}{*}{ Nutrient } & \multicolumn{12}{|c|}{ Ingredient } \\
\hline & $\mathrm{CS}^{1}$ & $\mathrm{AS}^{2}$ & $\mathrm{Hay}^{3}$ & $\mathrm{HMC}^{4}$ & $\mathrm{WCS}^{5}$ & $\mathrm{PRO}^{6}$ & $\mathrm{MV}^{7}$ & CntlM $^{8}$ & $\mathrm{NaBM}^{9}$ & $\mathrm{NaCM}^{10}$ & $\mathrm{KBM}^{11}$ & $\mathrm{KCM}^{12}$ \\
\hline $\mathrm{DM}, 55^{\circ} \mathrm{C}$ & 37.3 & 32.4 & 85.9 & 74.9 & 88.9 & 89.6 & 90.0 & 89.2 & 90.7 & 90.3 & 90.8 & 90.5 \\
\hline $\mathrm{DM}, 100^{\circ} \mathrm{C}$ & 35.5 & 30.7 & 82.7 & 72.2 & 85.9 & 86.8 & 87.4 & 85.8 & 87.0 & 87.1 & 87.4 & 87.7 \\
\hline $\mathrm{OM}$ & 96.4 & 90.1 & 89.1 & 98.6 & 96.3 & 93.8 & 69.9 & 88.9 & 81.4 & 78.0 & 75.7 & 75.2 \\
\hline Ash & 3.6 & 9.9 & 10.9 & 1.4 & 3.7 & 6.2 & 30.1 & 11.1 & 18.6 & 22.0 & 24.3 & 24.8 \\
\hline $\mathrm{CP}$ & 8.0 & 21.0 & 18.0 & 9.1 & 20.5 & 48.3 & 6.0 & 5.9 & 5.1 & 5.4 & 5.0 & 5.2 \\
\hline $\mathrm{NDF}$ & 40.4 & 43.3 & 39.3 & 9.6 & 45.4 & 16.7 & 6.6 & 39.3 & 25.5 & 29.8 & 23.0 & 27.3 \\
\hline Starch & 31.1 & 1.5 & 4.0 & 70.3 & 1.4 & 4.1 & 46.9 & 35.7 & 35.9 & 36.0 & 36.7 & 35.9 \\
\hline Ether extract & 4.4 & 5.8 & 2.3 & 3.4 & 17.7 & 4.0 & 1.6 & 1.2 & 6.6 & 1.3 & 2.2 & 1.4 \\
\hline $\mathrm{Na}$ & 0.09 & 0.07 & 0.05 & 0.04 & 0.07 & 0.10 & 3.39 & 0.06 & 5.37 & 5.40 & 0.07 & 0.23 \\
\hline $\mathrm{K}$ & 0.78 & 2.49 & 3.02 & 0.41 & 0.78 & 1.10 & 0.46 & 0.39 & 0.40 & 0.32 & 7.97 & 9.67 \\
\hline $\mathrm{Cl}$ & 0.17 & 0.54 & 0.56 & 0.06 & 0.05 & 0.07 & 5.07 & 0.09 & 0.07 & 8.19 & 0.08 & 8.46 \\
\hline
\end{tabular}

${ }^{1} \mathrm{CS}=$ corn silage.

${ }^{2} \mathrm{AS}=$ alfalfa silage.

${ }^{3}$ Hay $=$ mixed mostly alfalfa hay.

${ }^{4} \mathrm{HMC}=$ high moisture corn.

${ }^{5} \mathrm{WCS}=$ whole cottonseed .

${ }^{6} \mathrm{PRO}=$ Protein mix contained $75.6 \%$ soybean meal, $19.5 \%$ corn distillers grain, and $4.9 \%$ blood meal.

${ }^{7} \mathrm{MV}=$ Mineral and vitamin mix contained $69.4 \%$ dry ground corn, $10.5 \%$ dicalcium phosphate, $9.2 \%$ limestone, $8.1 \%$ trace mineral salt, $1.8 \%$ trace mineral premix, $0.4 \%$ magnesium oxide, $0.4 \%$ vitamin $\mathrm{A}, 0.3 \%$ vitamin $\mathrm{D}$, and $0.1 \%$ vitamin $\mathrm{E}$.

${ }^{8} \mathrm{CntlM}=$ control mix.

${ }^{9} \mathrm{NaBM}=$ sodium bicarbonate treatment mix.

${ }^{10} \mathrm{NaCM}=$ sodium chloride treatment mix.

${ }^{11} \mathrm{KBM}=$ potassium bicarbonate treatment mix.

${ }^{12} \mathrm{KCM}=$ potassium chloride treatment mix.

method (Karkalas, 1985) after samples were gelatinized with sodium hydroxide. Glucose concentration was measured using a glucose oxidase method (Glucose kit \#510; Sigma Chemical Co., St. Louis, MO), and ab- sorbance was determined with a microplate reader (SpectraMax 190, Molecular Devices Corp., Sunnyvale, $\mathrm{CA})$. Concentrations of NDF were determined according to Van Soest et al. (1991, method A). Concentrations of

Table 2. Ingredient composition of experimental diets (\% of dietary DM)

\begin{tabular}{|c|c|c|c|c|c|}
\hline \multirow[b]{2}{*}{ Diet ingredient } & \multicolumn{5}{|c|}{ Experimental diet } \\
\hline & Control & $\mathrm{NaBT}^{1}$ & $\mathrm{NaCT}^{2}$ & $\mathrm{KBT}^{3}$ & $\mathrm{KCT}^{4}$ \\
\hline Corn silage & 25.6 & 25.6 & 25.6 & 25.6 & 25.6 \\
\hline Alfalfa silage & 12.7 & 12.7 & 12.7 & 12.7 & 12.7 \\
\hline Mixed, mostly alfalfa hay & 6.0 & 6.0 & 6.0 & 6.0 & 6.0 \\
\hline High moisture corn & 23.5 & 23.5 & 23.5 & 23.5 & 23.5 \\
\hline Whole cottonseed & 7.2 & 7.2 & 7.2 & 7.2 & 7.2 \\
\hline Protein mix $^{5}$ & 15.1 & 15.1 & 15.1 & 15.1 & 15.1 \\
\hline Mineral and vitamin $\operatorname{mix}^{6}$ & 5.0 & 5.0 & 5.0 & 5.0 & 5.0 \\
\hline Treatment mix & 5.0 & 5.0 & 5.0 & 5.0 & 5.0 \\
\hline Dried, ground corn & 2.5 & 2.5 & 2.5 & 2.5 & 2.5 \\
\hline Ground rice hulls & 2.5 & 1.5 & 1.8 & 1.3 & 1.6 \\
\hline $\mathrm{NaCl}$ & - & - & 0.7 & - & - \\
\hline $\mathrm{KCl}$ & - & - & - & - & 0.9 \\
\hline $\mathrm{NaHCO}_{3}$ & - & 1.0 & - & - & - \\
\hline $\mathrm{KHCO}_{3}$ & - & - & - & 1.2 & - \\
\hline
\end{tabular}

${ }^{1} \mathrm{NaBT}=$ sodium bicarbonate treatment diet.

${ }^{2} \mathrm{NaCT}=$ sodium chloride treatment diet.

${ }^{3} \mathrm{KBT}=$ potassium bicarbonate treatment diet.

${ }^{4} \mathrm{KCT}=$ potassium chloride treatment diet.

${ }^{5}$ Protein mix contained $75.6 \%$ soybean meal, $19.5 \%$ corn distillers grain, and $4.9 \%$ blood meal.

${ }^{6}$ Mineral and vitamin mix contained $69.4 \%$ dry ground corn, $10.5 \%$ dicalcium phosphate, $9.2 \%$ limestone, $8.1 \%$ trace mineral salt, $1.8 \%$ trace mineral premix, $0.4 \%$ magnesium oxide, $0.4 \%$ vitamin $\mathrm{A}, 0.3 \%$ vitamin $\mathrm{D}$, and $0.1 \%$ vitamin $\mathrm{E}$. 
Table 3. Composition of experimental diets (\% of dietary DM)

\begin{tabular}{|c|c|c|c|c|c|}
\hline \multirow[b]{2}{*}{ Item } & \multicolumn{5}{|c|}{ Experimental diet } \\
\hline & Control & $\mathrm{NaBT}^{1}$ & $\mathrm{NaCT}^{2}$ & $\mathrm{KBT}^{3}$ & $\mathrm{KCT}^{4}$ \\
\hline $\mathrm{DM}, 105^{\circ} \mathrm{C}$ & 52.5 & 52.5 & 52.5 & 52.5 & 52.5 \\
\hline $\mathrm{OM}$ & 93.6 & 93.2 & 93.1 & 92.9 & 92.9 \\
\hline Ash & 6.4 & 6.8 & 6.9 & 7.1 & 7.1 \\
\hline Starch & 29.9 & 29.9 & 29.9 & 29.9 & 29.9 \\
\hline NDF & 28.5 & 27.8 & 28.0 & 27.7 & 27.9 \\
\hline $\mathrm{CP}$ & 17.2 & 17.2 & 17.2 & 17.2 & 17.2 \\
\hline Ether extract & 4.8 & 4.8 & 4.5 & 4.6 & 4.5 \\
\hline $\mathrm{Na}$ & 0.23 & 0.50 & 0.50 & 0.23 & 0.24 \\
\hline $\mathrm{K}$ & 1.06 & 1.06 & 1.06 & 1.44 & 1.52 \\
\hline $\mathrm{Cl}$ & 0.43 & 0.43 & 0.83 & 0.43 & 0.85 \\
\hline $\mathrm{S}$ & 0.14 & 0.14 & 0.14 & 0.14 & 0.14 \\
\hline Forage & 44.3 & 44.3 & 44.3 & 44.3 & 44.3 \\
\hline Forage NDF & 18.2 & 18.2 & 18.2 & 18.2 & 18.2 \\
\hline DCAD $3{ }^{5} \mathrm{mEq} / 100 \mathrm{~g}$ of DM & 25.1 & 36.7 & 25.2 & 34.8 & 25.6 \\
\hline $\mathrm{DCAD} 4,{ }^{6} \mathrm{mEq} / 100 \mathrm{~g}$ of $\mathrm{DM}$ & 16.1 & 27.6 & 16.2 & 25.8 & 16.6 \\
\hline
\end{tabular}

all nutrients except for DM are expressed as percentages of $\mathrm{DM}$ determined by drying at $105^{\circ} \mathrm{C}$ in a forcedair oven for more than $8 \mathrm{~h}$.

Feed samples were analyzed for sodium, potassium, chloride, and sulfur. Sodium and potassium were determined by digestion according to Hach et al. (1987) and measurement of the elements in the supernate by atomic absorption according to manufacturer's recommendation (SpectrAA 220FS, Atomic Absorption Spectrometer, Varian Analytical Instruments, Walnut Creek, CA). Chloride was determined by extracting the feed with $1.0 \%$ nitric acid solution for one hour on a shaker (Orbimix 1010, Brinkman Instruments, Westbury, NY) and measuring chloride in the supernate by coulometric titration (Digital Chloridometer, model 442-5000, Labconco Corporation, Kansas City, MO). Digests and dilutions were stored in polypropylene containers until analysis; either polypropylene specimen cups or polypropylene, round bottom, $13 \times 100 \mathrm{~mm}$, culture test tubes (Fisherbrand Catalog No. 14-956-7A, Fisher Scientific, Pittsburgh, PA). Dried and ground samples of the base mix, rice hulls, and dried, ground corn were composited across periods and sent to Dairy One Forage Laboratory (Ithaca, NY) for sulfur analysis according to manufacturer's recommendation (Leco Application Note 203-601-229, 08/92, Leco model SC-432, St. Joseph, MI).

\section{Calculations}

Dry matter intake and nutrient intake were calculated by subtracting the amount refused from amount offered. Nutrient intake calculations assume that the diet was combined exactly as prescribed on the mix sheet. Orts were not analyzed for starch, chloride, sodium, and potassium, and therefore, intake calculations assume that concentrations of starch, chloride, sodium, and potassium in the orts were equal to the concentrations in the DM offered. Change in BW and BCS were calculated by subtracting the beginning period value from end of period value. Yield of SCM was calculated (Tyrrell and Reid, 1965), as was yield of FCM (NRC, 2001). Somatic cell score was calculated as the log (base 2) of SCC.

Manually observed chewing activity was summarized by a logic script in Igor Pro (Version 4.07 Carbon 2003, WaveMetrics Inc., Lake Oswego, OR) to generate meal and rumination bout information according to previously established criteria (Dado and Allen, 1994). Variables determined included frequency of meal bouts per day, interval between meals, frequency of ruminating bouts per day, interval between ruminating bouts, eating time per day, ruminating time per day, and total chewing time per day.

Three cow periods from 2 cows were excluded from the data set because of health problems unrelated to the experiment. If a milk sample or weight was not obtained at an individual milking, the milk data for the entire cow day was removed; $35 \mathrm{~d}$ of milk data out of a possible 800 were removed from the final data set.

\section{Statistical Analysis}

All data (cow-period means) were analyzed using the fit model procedure of JMP (Version 5.0.1.2. 2003, SAS 
Institute Inc., Cary, NC) according to the following model:

$$
\mathrm{Y}_{\mathrm{ijk}}=\mu+\mathrm{C}_{\mathrm{i}}+\mathrm{P}_{\mathrm{j}}+\mathrm{T}_{\mathrm{k}}+\mathrm{O}_{\mathrm{ij}}+\mathrm{e}_{\mathrm{ijk}},
$$

where $\mu=$ overall mean, $C_{i}=$ random effect of cow $(i=$ 1 to 40$), P_{j}=$ fixed effect of period ( $\mathrm{j}=1$ to 5$), \mathrm{T}_{\mathrm{k}}=$ fixed effect of treatment ( $k=1$ to 5 ), $\mathrm{O}_{\mathrm{ij}}=$ fixed effect of treatment carryover, and $\mathrm{e}_{\mathrm{ijk}}=$ residual, assumed to be normally distributed.

Orthogonal contrasts were performed for effects of ion treatments vs. control, cation treatments (sodium vs. potassium), anion treatments (bicarbonate vs. chloride), and interaction of cation and anion treatments. Treatment effects and their interaction were declared significant at $P<0.05$ and $P<0.10$, respectively, and tendency for treatment effects were declared at $P<$ 0.10 . When interactions of main effects were significant, treatment means were compared using Student's $t$-test, and differences were declared significant at $P<0.05$. Milk yield and composition cow-period means were weighted because of missing data for some days.

Residual plots were inspected visually for the appearance of normality; plots for all variables appeared normally distributed except for SCC. The SCC data were transformed to SCS, and the associated residual plot appeared to be normally distributed. Period $\times$ treatment interaction was evaluated originally, but it was removed from the statistical model because this interaction was never significant.

\section{RESULTS}

Treatments did not affect intake of DM and OM, which were 27.9 and $25.0 \mathrm{~kg}$, respectively. The NDF intake for the control diet tended to increase slightly when compared with the ion treatments ( $7.5 \mathrm{vs} .7 .4 \mathrm{~kg}$ ) because of a greater proportion of rice hulls. Sodium, potassium, and chloride intakes were as expected according to the experimental design. A uniform cation intake was achieved across all treatment diets, averaging $3.3 \mathrm{~mol} / \mathrm{cow} / \mathrm{d}$ (Table 4 ).

Ion treatments affected milk yield and composition (Table 5). Potassium treatments tended to increase yield of milk fat and milk lactose as well as componentcorrected milk yield (3.5\% FCM and SCM) when compared with sodium treatments. Bicarbonate treatments increased milk fat $(0.12$ percentage units and $0.07 \mathrm{~kg} /$ d), milk lactose (0.06 percentage units and $0.06 \mathrm{~kg} / \mathrm{d})$, and SNF $(0.05$ percentage units and $0.10 \mathrm{~kg} / \mathrm{d})$ when compared with chloride treatments. Bicarbonate treatments increased yield of milk $(0.8 \mathrm{~kg} / \mathrm{d})$ and increased yield of both fat- and solids-corrected milk by $1.5 \mathrm{~kg} / \mathrm{d}$ when compared with chloride treatments. The interac- tion among cations and anions was significant for SNF percentage $(P=0.08)$, and Student's $t$-test showed the 2 bicarbonate treatments $(8.71 \%)$ were greater than the sodium chloride treatment $(8.63 \%)$. Ion treatments did not affect SCC or SCS $(P>0.30)$. Bicarbonate treatments also increased efficiency of yield of both fat- and solids-corrected milk ( 0.06 and $0.05 \mathrm{~kg} / \mathrm{kg}$, respectively) when compared with chloride treatments (Table 6). These results would be conservative if microbial populations in the rumen were not fully adapted to treatments.

All experimental diets resulted in a gain in BCS and BW across the test periods (Table 6) indicating that these midlactation cows were in positive energy balance. However, an interaction among treatments $(P=$ 0.06) was detected for BW; both sodium treatments resulted in similar BW gain (10.8 kg/period), but the potassium chloride treatment resulted in more than twice the gain as potassium bicarbonate treatment (15.1 vs. $7.0 \mathrm{~kg} /$ period).

Ion treatments decreased chewing activity (Table 7). Meal frequency was similar across all diets (8.0 meals/ d) and meal length was decreased with ion treatments ( $2.1 \mathrm{~min} / \mathrm{meal})$, but total eating time per day was similar across all diets $(273.3 \mathrm{~min} / \mathrm{d})$. The number of ruminating bouts per day was similar across diets (14.3 bouts/ d), but ion treatments decreased ruminating bout length $(1.6 \mathrm{~min} / \mathrm{bout})$ and total ruminating time per day $(26.2 \mathrm{~min} / \mathrm{d})$. Even when ruminating time $(\mathrm{min} / \mathrm{d})$ was corrected for intake (DM and NDF), the depression by ion treatments remained $(1.0 \mathrm{~min} / \mathrm{kg}$ of $\mathrm{DM}$ and 2.5 $\mathrm{min} / \mathrm{kg}$ of NDF). Ion treatments had similar effects on total chewing time $(\mathrm{min} / \mathrm{d})$ with the decreases in eating and ruminating time resulting in a decrease in total chewing time by $28.2 \mathrm{~min} / \mathrm{d}$. No specific cation or anion effects were observed for chewing activity.

\section{DISCUSSION}

Two unique elements of this experiment compared with others reported in the literature are the equimolar addition of cations and anions and the commonality of greater than $98 \%$ of the dietary DM across experimental diets. These elements along with the uniform DMI allowed the separation of specific ion and general osmotic effects.

\section{Production and Performance}

The DMI $(27.9 \mathrm{~kg} / \mathrm{d})$ and milk production $(38.8 \mathrm{~kg} / \mathrm{d})$ recorded in this experiment were similar to the highest of sodium bicarbonate studies reviewed by Staples and Lough (1989). Intake was similar across all experimental diets, but performance differed, which is consistent with previous reports (Erdman, 1988; Staples and 
Table 4. The effect of dietary strong ion treatment on component intakes

\begin{tabular}{|c|c|c|c|c|c|c|c|c|c|c|}
\hline \multirow[b]{2}{*}{ Item } & \multicolumn{5}{|c|}{ Experimental diet } & \multirow[b]{2}{*}{$\mathrm{SE}$} & \multicolumn{4}{|c|}{$P$-value } \\
\hline & Control & $\mathrm{NaBT}^{1}$ & $\mathrm{NaCT}^{2}$ & $\mathrm{KBT}^{3}$ & $\mathrm{KCT}^{4}$ & & TMT $^{5}$ & Cation $^{6}$ & Anion $^{7}$ & $\mathrm{X}^{8}$ \\
\hline $\mathrm{DMI}, \mathrm{kg} / \mathrm{d}$ & 27.8 & 27.8 & 27.8 & 28.0 & 28.0 & 0.4 & 0.66 & 0.46 & 0.90 & 0.94 \\
\hline NDF intake, $\mathrm{kg} / \mathrm{d}$ & 7.5 & 7.3 & 7.4 & 7.3 & 7.4 & 0.1 & 0.06 & 0.93 & 0.20 & 0.68 \\
\hline $\mathrm{CP}$ intake, kg/d & 4.6 & 4.6 & 4.6 & 4.6 & 4.6 & 0.1 & 0.85 & 0.37 & 0.72 & 0.97 \\
\hline Estimated ${ }^{9}$ starch intake, $\mathrm{kg} / \mathrm{d}$ & 8.0 & 8.0 & 8.0 & 8.0 & 8.0 & 0.1 & 0.59 & 0.37 & 0.83 & 0.82 \\
\hline Estimated $^{9}$ treatment intake, $\mathrm{kg} / \mathrm{d}$ & 1.4 & 1.4 & 1.4 & 1.4 & 1.4 & $<0.1$ & 0.66 & 0.46 & 0.90 & 0.93 \\
\hline Estimated $^{9}$ chloride intake, $\mathrm{kg} / \mathrm{d}$ & 0.115 & 0.115 & 0.223 & 0.115 & 0.228 & 0.002 & $<0.001$ & 0.04 & $<0.001$ & 0.07 \\
\hline Estimated ${ }^{9}$ cation intake from treatment mix,${ }^{10} \mathrm{~mol} / \mathrm{d}$ & 0.0 & 3.3 & 3.3 & 3.3 & 3.3 & $<0.1$ & $<0.001$ & 0.74 & 1.00 & 0.93 \\
\hline
\end{tabular}

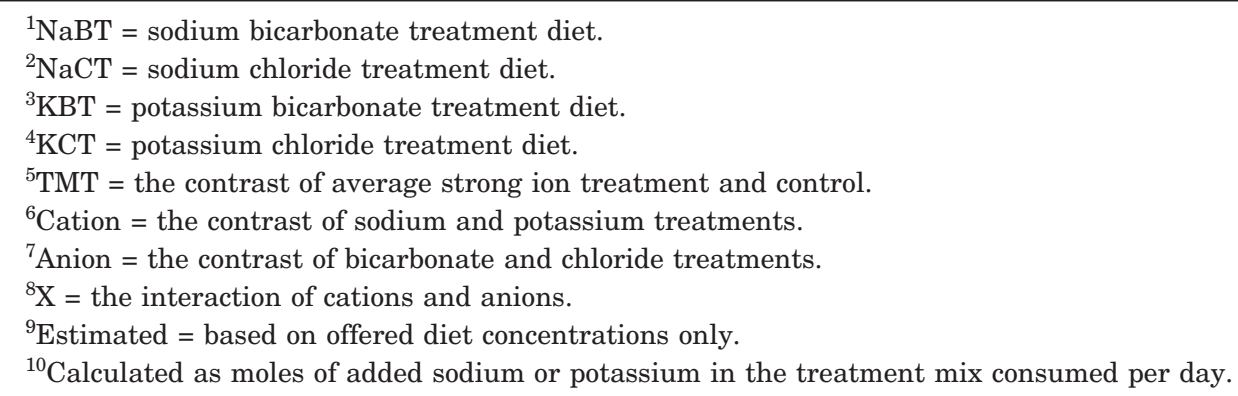

Lough, 1989). The increase in FCM yield without a corresponding increase in DMI suggests either an increase in digestibility or a change in nutrient partitioning.

Dietary cation-anion difference for diets without bicarbonate in this experiment was less than that re- quired for maximum milk yield according to the metaanalysis of $\mathrm{Hu}$ and Murphy (2004). However, in that meta-analysis, response in milk yield and DMI was very broad, and there was little difference in animal response between the optimum and the DCAD of diets not containing bicarbonate. In addition, many of the

Table 5. The effect of dietary strong ion treatment on milk production and milk composition

\begin{tabular}{|c|c|c|c|c|c|c|c|c|c|c|}
\hline \multirow[b]{2}{*}{ Item } & \multicolumn{5}{|c|}{ Experimental diet } & \multirow[b]{2}{*}{$\mathrm{SE}$} & \multicolumn{4}{|c|}{$P$-value } \\
\hline & Control & $\mathrm{NaBT}^{1}$ & $\mathrm{NaCT}^{2}$ & $\mathrm{KBT}^{3}$ & $\mathrm{KCT}^{4}$ & & $\mathrm{TMT}^{5}$ & Cation $^{6}$ & Anion $^{7}$ & $\mathrm{X}^{8}$ \\
\hline Milk, kg/d & 36.4 & 37.3 & 36.3 & 37.7 & 37.0 & 1.2 & 0.16 & 0.16 & 0.05 & 0.69 \\
\hline Milk fat, $\%$ & 3.83 & 3.88 & 3.74 & 3.89 & 3.80 & 0.07 & 0.87 & 0.32 & 0.001 & 0.53 \\
\hline Milk protein, \% & 3.12 & 3.12 & 3.12 & 3.10 & 3.13 & 0.03 & 0.89 & 0.72 & 0.25 & 0.19 \\
\hline Milk lactose, $\%$ & 4.69 & 4.73 & 4.66 & 4.73 & 4.69 & 0.03 & 0.36 & 0.17 & $<0.001$ & 0.22 \\
\hline Milk SNF, \% & $8.68^{\mathrm{ab}}$ & $8.72^{\mathrm{a}}$ & $8.63^{b}$ & $8.70^{\mathrm{a}}$ & $8.69^{\mathrm{ab}}$ & 0.06 & 0.70 & 0.39 & 0.04 & 0.08 \\
\hline Milk fat, $\mathrm{kg} / \mathrm{d}$ & 1.40 & 1.45 & 1.36 & 1.46 & 1.41 & 0.05 & 0.44 & 0.08 & 0.001 & 0.42 \\
\hline Milk protein, $\mathrm{kg} / \mathrm{d}$ & 1.13 & 1.16 & 1.12 & 1.16 & 1.15 & 0.03 & 0.17 & 0.23 & 0.10 & 0.48 \\
\hline Milk lactose, $\mathrm{kg} / \mathrm{d}$ & 1.72 & 1.77 & 1.70 & 1.79 & 1.74 & 0.06 & 0.16 & 0.10 & 0.06 & 0.53 \\
\hline Milk SNF, kg/d & 3.16 & 3.25 & 3.13 & 3.28 & 3.21 & 0.10 & 0.17 & 0.12 & 0.02 & 0.48 \\
\hline $3.5 \% \mathrm{FCM}, \mathrm{kg} / \mathrm{d}$ & 38.4 & 39.5 & 37.6 & 39.9 & 38.8 & 1.3 & 0.28 & 0.08 & 0.002 & 0.47 \\
\hline $\mathrm{SCM}, \mathrm{kg} / \mathrm{d}$ & 35.2 & 36.3 & 34.5 & 36.7 & 35.6 & 1.2 & 0.26 & 0.08 & 0.001 & 0.40 \\
\hline $\mathrm{SCC}, 1,000$ cells $/ \mathrm{mL}$ & 178 & 219 & 240 & 297 & 205 & 70 & 0.36 & 0.72 & 0.55 & 0.34 \\
\hline SCS & 2.7 & 2.5 & 2.8 & 2.5 & 2.6 & 0.3 & 0.71 & 0.66 & 0.30 & 0.52 \\
\hline
\end{tabular}

${ }^{\mathrm{a}, \mathrm{b}}$ Means within a row with different superscripts differ (Student's $t$-test, $P<0.05$ ).

${ }^{1} \mathrm{NaBT}=$ sodium bicarbonate treatment diet.

${ }^{2} \mathrm{NaCT}=$ sodium chloride treatment diet.

${ }^{3} \mathrm{KBT}=$ potassium bicarbonate treatment diet.

${ }^{4} \mathrm{KCT}=$ potassium chloride treatment diet.

${ }^{5} \mathrm{TMT}=$ the contrast of average strong ion treatment and control.

${ }^{6}$ Cation $=$ the contrast of sodium and potassium treatments.

${ }^{7}$ Anion $=$ the contrast of bicarbonate and chloride treatments.

${ }^{8} \mathrm{X}=$ the interaction of cations and anions. 
Table 6. The effect of dietary strong ion treatment on BW, BCS, and milk production efficiency

\begin{tabular}{|c|c|c|c|c|c|c|c|c|c|c|}
\hline \multirow[b]{2}{*}{ Item } & \multicolumn{5}{|c|}{ Experimental diet } & \multirow[b]{2}{*}{ SE } & \multicolumn{4}{|c|}{$P$-value } \\
\hline & Control & $\mathrm{NaBT}^{1}$ & $\mathrm{NaCT}^{2}$ & $\mathrm{KBT}^{3}$ & $\mathrm{KCT}^{4}$ & & $\mathrm{TMT}^{5}$ & Cation $^{6}$ & Anion $^{7}$ & $\mathrm{X}^{8}$ \\
\hline Change in BW, kg/14 d & $7.6^{\mathrm{b}}$ & $10.7^{\mathrm{ab}}$ & $10.9^{\mathrm{ab}}$ & $7.0^{\mathrm{b}}$ & $15.1^{\mathrm{a}}$ & 2.0 & 0.15 & 0.91 & 0.05 & 0.06 \\
\hline Change in BCS, change/14 d & 0.04 & 0.08 & 0.11 & 0.06 & 0.05 & 0.03 & 0.26 & 0.16 & 0.90 & 0.46 \\
\hline Milk per DMI, $\mathrm{kg} / \mathrm{kg}$ & 1.31 & 1.34 & 1.30 & 1.35 & 1.33 & 0.04 & 0.27 & 0.27 & 0.08 & 0.76 \\
\hline $3.5 \% \mathrm{FCM} / \mathrm{DMI}, \mathrm{kg} / \mathrm{kg}$ & 1.38 & 1.42 & 1.35 & 1.43 & 1.39 & 0.04 & 0.41 & 0.18 & 0.01 & 0.59 \\
\hline $\mathrm{SCM}$ per DMI, kg/kg & 1.27 & 1.30 & 1.24 & 1.31 & 1.28 & 0.04 & 0.41 & 0.17 & 0.008 & 0.50 \\
\hline \multicolumn{11}{|c|}{${ }^{\mathrm{a}, \mathrm{b}}$ Means within a row with different superscripts differ (Student's $t$-test, $P<0.05$ ). } \\
\hline \multicolumn{11}{|c|}{${ }^{1} \mathrm{NaBT}=$ sodium bicarbonate treatment diet. } \\
\hline \multicolumn{11}{|c|}{${ }^{2} \mathrm{NaCT}=$ sodium chloride treatment diet. } \\
\hline \multicolumn{11}{|c|}{${ }^{3} \mathrm{KBT}=$ potassium bicarbonate treatment diet. } \\
\hline \multicolumn{11}{|c|}{${ }^{4} \mathrm{KCT}=$ potassium chloride treatment diet. } \\
\hline \multicolumn{11}{|c|}{${ }^{5} \mathrm{TMT}=$ the contrast of average strong ion treatmen } \\
\hline \multicolumn{11}{|c|}{${ }^{6}$ Cation $=$ the contrast of sodium and potassium treatments. } \\
\hline${ }^{7}$ Anion $=$ the contrast of bi & arbonate & and chlo & ride tre & 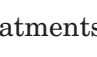 & & & & & & \\
\hline
\end{tabular}

diets in that analysis contained bicarbonate, and it is impossible to separate the effects of bicarbonate from DCAD. Sodium bicarbonate might increase FCM in several possible ways. Sodium bicarbonate may buffer, increasing ruminal $\mathrm{pH}$ and fiber digestion in the $\mathrm{RR}$ (Erdman et al., 1982). Sodium bicarbonate addition might also alter rate and extent of biohydrogenation of fatty acids by ruminal microbes, decreasing trans fatty acids flowing from the RR (Kalscheur et al., 1997). However, the mechanism of action cannot be concluded from this experiment. Potassium bicarbonate has been shown to be as effective as sodium bicarbonate for relieving milk fat depression (Emery, 1976).

\section{Chewing Activity}

Meals were slightly shorter and meal frequency was numerically higher with ion treatment, and the total DMI was similar across all diets. Infusion of sodium chloride at spontaneous meals $(2.25 \mathrm{~mol}$ over $5 \mathrm{~min})$ decreased meal size $28 \%$, but feed intake was not affected because intermeal interval decreased $32 \%$ (Choi

Table 7. The effect of strong ion treatment on feeding behavior and chewing activity

\begin{tabular}{|c|c|c|c|c|c|c|c|c|c|c|}
\hline Item & \multicolumn{5}{|c|}{ Experimental diet } & $\mathrm{SE}$ & \multicolumn{4}{|c|}{$P$-value } \\
\hline Meals, /d & 7.8 & 7.9 & 8.1 & 8.1 & 8.3 & 0.2 & 0.18 & 0.29 & 0.29 & 0.87 \\
\hline Eating time, $\mathrm{min} / \mathrm{d}$ & 275.0 & 273.9 & 270.4 & 274.6 & 272.6 & 7.2 & 0.67 & 0.74 & 0.54 & 0.87 \\
\hline Intermeal interval, min & 115.5 & 113.2 & 111.4 & 109.5 & 111.1 & 3.3 & 0.20 & 0.50 & 0.97 & 0.56 \\
\hline Ruminating bout, $\mathrm{n}$ & 14.4 & 14.4 & 13.9 & 14.4 & 14.4 & 0.3 & 0.52 & 0.27 & 0.33 & 0.27 \\
\hline Ruminating bout length, min & 36.5 & 34.5 & 35.6 & 34.4 & 35.1 & 1.0 & 0.01 & 0.57 & 0.13 & 0.74 \\
\hline Total chewing time, min/d & 791.8 & 764.0 & 756.7 & 763.8 & 769.7 & 13.7 & 0.003 & 0.44 & 0.93 & 0.42 \\
\hline Eating time/DMI, $\mathrm{min} / \mathrm{kg}$ & 10.0 & 9.9 & 9.8 & 9.9 & 9.8 & 0.27 & 0.51 & 0.99 & 0.50 & 0.84 \\
\hline Ruminating time $/ \mathrm{DMI}, \mathrm{min} / \mathrm{kg}$ & 18.7 & 17.7 & 17.5 & 17.6 & 17.9 & 0.38 & $<0.001$ & 0.68 & 0.87 & 0.26 \\
\hline Total chewing/DMI, $\mathrm{min} / \mathrm{kg}$ & 28.6 & 27.6 & 27.2 & 27.4 & 27.6 & 0.53 & 0.002 & 0.75 & 0.80 & 0.33 \\
\hline Eating time/NDF intake, $\mathrm{min} / \mathrm{kg}$ & 37.1 & 37.7 & 36.6 & 37.7 & 37.1 & 1.05 & 0.77 & 0.70 & 0.18 & 0.72 \\
\hline Ruminating time/NDF intake, $\mathrm{min} / \mathrm{kg}$ & 69.5 & 67.6 & 65.7 & 67.2 & 67.7 & 1.51 & 0.02 & 0.36 & 0.45 & 0.17 \\
\hline Total chewing/NDF intake, $\mathrm{min} / \mathrm{kg}$ & 106.5 & 105.3 & 102.3 & 104.9 & 104.8 & 2.09 & 0.10 & 0.36 & 0.19 & 0.22 \\
\hline
\end{tabular}

${ }^{1} \mathrm{NaBT}=$ sodium bicarbonate treatment diet.

${ }^{2} \mathrm{NaCT}=$ sodium chloride treatment diet.

${ }^{3} \mathrm{KBT}=$ potassium bicarbonate treatment diet.

${ }^{4} \mathrm{KCT}=$ potassium chloride treatment diet.

${ }^{5} \mathrm{TMT}=$ the contrast of average strong ion treatment and control.

${ }^{6}$ Cation $=$ the contrast of sodium and potassium treatments.

${ }^{7}$ Anion $=$ the contrast of bicarbonate and chloride treatments.

${ }^{8} \mathrm{X}=$ the interaction of cations and anions. 
and Allen, 1999). However, with ion treatment in this experiment, the increase in ruminal osmolality during meals would likely be smaller. Meal size (kg) was not determined in this experiment, so it is not known if shorter meal length resulted in smaller meals.

Ion treatments decreased chewing activity, but the effect was general and not specific to cations or anions. Without a specific ion effects, these effects must be due to direct or indirect effects of increased ruminal osmolality. Increasing ruminal osmolality can cause rumination to cease. Welch (1982) proposed a ruminal osmotic threshold for termination of rumination in sheep where rumination would cease when ruminal osmolality was greater than $350 \mathrm{mOsm}$.

All the components of treatments (sodium, potassium, bicarbonate, and chloride) are osmotically active (Weast, 1978) and increase the osmolality of the $R R$ solution when consumed although the osmotic effect of bicarbonate is expected to be more transitory than the other ions. Given the measured dietary composition and average meal size and assuming a RR volume of $50 \mathrm{~L}$ (Andrew et al., 1995), the ruminal osmolality could increase up to $15 \mathrm{mOsm} / \mathrm{L}$ with the inclusion of the ion treatments in the treatment diets.

Inclusion of ion treatments will likely result in a small, sustained increase in ruminal osmolality, thereby reducing ruminating time per bout by several possible mechanisms. One possibility is that stimulation of chemoreceptors in the RR wall decreases rumination. Sheep will modify intake behavior in response to ruminal osmolality changes within the physiological range (Carter and Grovum, 1990), and the effect can be negated by the application of a local anesthetic (Bergen, 1972). However, chemoreceptors that respond to the physiological range in ruminal osmolality have not been specifically identified (Leek and Harding, 1975). Another possible mechanism might be related to changes in the osmotic pressure difference between the ruminal solution and the blood. The normally lower osmolality of the ruminal solution compared with blood leads to an osmotic pressure against the ruminal wall (Engelhardt, 1970). As ruminal osmolality increases, the osmotic pressure across the ruminal wall is reduced, decreasing stimulation of the tension and epithelial receptors of the $R R$. Increased stimulation of these receptors is usually associated with increased rumination (Leek, 2004). Other possible mechanisms might be through effects of ruminal osmolality on ruminal motility, which may reduce the stimulation of rumination or systemic effects related to increased plasma osmolality. Clearly, induction and termination of rumination is complex, and our understanding of the mechanism by which ion treatments decreased rumination remains incomplete.
Table 8. Estimated saliva flow on the control diet based on chewing activity and expected saliva flows

\begin{tabular}{lccc}
\hline $\begin{array}{l}\text { Chewing } \\
\text { activity }\end{array}$ & Min/d & $\begin{array}{c}\text { Saliva } \\
\mathrm{mL} / \mathrm{min}^{1}\end{array}$ & $\begin{array}{c}\text { Saliva } \\
\mathrm{L} / \mathrm{d}\end{array}$ \\
\hline Eating & 275 & 201 & 55 \\
Ruminating & 520 & 249 & 129 \\
Idle & 645 & 126 & 81 \\
Total & 1,440 & - & $265^{2}$ \\
\hline
\end{tabular}

${ }^{1}$ Mean of values reported by Cassida and Stokes, 1986, and Maekawa et al., 2002.

${ }^{2}$ If lactating cow saliva is $150 \mathrm{mEq} / \mathrm{L}$ of bicarbonate equivalent (see Erdman, 1988, for definition), then $265 \mathrm{~L}$ has $39,750 \mathrm{mEq}$ of bicarbonate equivalent.

\section{Cost and Benefits of Sodium Bicarbonate Addition}

With the increase in milk production and a reduction in rumination, cost and benefits associated with the addition of sodium bicarbonate to the diet should be considered. Cost and benefits can be determined for economics as well as ruminal buffering. The mean consumption of $279 \mathrm{~g} / \mathrm{d}$ of sodium bicarbonate costs $\$ 0.112 /$ $\mathrm{d}$ (assuming a cost of $\$ 360 / \mathrm{t}$ ), but the return for increased production of $1.4 \mathrm{~kg}$ of milk is $\$ 0.372$ (assuming $\$ 12 / 45.4 \mathrm{~kg}$ of milk). The addition of sodium bicarbonate is profitable for these conditions across a range of milk prices and sodium bicarbonate costs.

Sodium bicarbonate addition also results in a net gain in ruminal buffering. A loss of $26 \mathrm{~min} / \mathrm{d}$ of rumination time is expected to result in a loss of $480 \mathrm{mEq}$ of bicarbonate equivalent [ $(26 \mathrm{~min}$ lost/d $) \times(0.123 \mathrm{~L}$ of saliva less/min $) \times(150 \mathrm{mEq}$ of bicarbonate equivalent/ $\mathrm{L}$ of saliva)]. However, consumption of $279 \mathrm{~g} / \mathrm{d}$ of sodium bicarbonate delivers $3,298 \mathrm{mEq}$ of bicarbonate equivalent to the $R R$ for a net gain of $2,818 \mathrm{mEq}$ of bicarbonate equivalent. As a point of comparison, the measured chewing times of the control diet in this experiment would generate saliva containing almost $40 \mathrm{Eq}$ of bicarbonate equivalent per day (Table 8) given published valves for saliva flow (Cassida and Stokes, 1986; Maekawa et al., 2002) and bicarbonate equivalent composition (Erdman, 1988).

\section{CONCLUSIONS}

All ion treatments decreased rumination time in this typical lactating cow diet. The effect was not specific to sodium but was likely through increased ruminal osmolality that decreased the length of rumination bouts. The specific mechanism by which increased osmolality of ruminal fluid results in decreased rumination remains to be defined. The gain in ruminal buffering by addition of sodium bicarbonate addition was calculated to be greater than the loss from reduced rumination in this experiment. 


\section{ACKNOWLEDGMENTS}

The authors thank R. Longuski, D. G. Main, Y. Ying, M. Oba, J. Linton, B. Kreft, and the staff of the Michigan State University Dairy Cattle Teaching and Research Center for their assistance with this experiment.

\section{REFERENCES}

Allen, M. S. 1997. Relationship between fermentation acid production in the rumen and the requirement for physically effective fiber. J. Dairy Sci. 80:1447-1462.

Andrew, S. M., R. A. Erdman, and D. R. Waldo. 1995. Prediction of body composition of dairy cows at three physiological stages from deuterium oxide and urea dilution. J. Dairy Sci. 78:1083-1095.

AOAC. 2003. Official Method 33.2.31. In Official Methods of Analysis. Vol. II. 17th ed., Rev. 2. W. Horwitz, ed. AOAC International, Gaithersburg, MD.

Bailey, C. B., and C. C. Balch. 1961. Saliva secretion and its relation to feeding in cattle 2 . The composition and rate of secretion of mixed saliva in the cow during rest. Br. J. Nutr. 15:383-402.

Bergen, W. G. 1972. Rumen osmolality as a factor in feed intake control of sheep. J. Anim. Sci. 34:1054-1060.

Carter, R. R., and W. L. Grovum. 1990. Factors affecting the voluntary intake of food by sheep. 5 . The inhibitory effect of hypertonicity in the rumen. Br. J. Nutr. 64:285-299.

Cassida, K. A., and M. R. Stokes. 1986. Eating and resting salivation in early lactation dairy cows. J. Dairy Sci. 69:1282-1292.

Choi, B. R., and M. S. Allen. 1999. Intake regulation by volatile fatty acids and physical fill. S. Afr. J. Anim. Sci. 29(ISRP):4041. (Abstr.)

Dado, R. G., and M. S. Allen. 1994. Variation in and relationships among feeding, chewing, and drinking variables for lactating dairy cows. J. Dairy Sci. 77:132-144.

Emery, R. S. 1976. High energy feeds for milk production. Pages 149 156 in Buffers in Ruminant Physiology and Metabolism. Church and Dwight Company Inc., New York, NY.

Engelhardt, W. V. 1970. Movement of water across the rumen epithelium. Pages 132-146 in Physiology of Digestion and Metabolism in the Ruminant. Proc. 3rd Int. Symp. A. T. Phillipson. ed. Oriel Press Limited, Newcastle upon Tyne, UK.

Erdman, R. A. 1988. Dietary buffering requirements of the lactating dairy cow: A review. J. Dairy Sci. 71:3246-3266.

Erdman, R. A., R. W. Hemken, and L. S. Bull. 1982. Dietary sodium bicarbonate and magnesium oxide for early postpartum lactating dairy cows: Effects on production, acid-base metabolism, and digestion. J. Dairy Sci. 65:712-731.
Hach, C. C., B. K. Bowden, A. B. Lopelove, and S. V. Brayton. 1987. More powerful peroxide Kjeldahl digestion method. J. AOAC 70:783-787.

Hogue, J. F., W. B. Tucker, M. T. Van Koevering, R. K. Vernon, and G. D. Adams. 1991. Controlled ruminal infusion of sodium bicarbonate. 1. Influence of postfeeding infusion interval on ruminal milieu. J. Dairy Sci. 74:1675-1683.

Hu, W., and M. R. Murphy. 2004. Dietary cation-anion difference effects on performance and acid-base status of lactating dairy cows: A meta-analysis. J. Dairy Sci. 87:2222-2229.

Kalscheur, K. F., B. B. Teter, L. S. Piperova, and R. A. Erdman. 1997. Effect of dietary forage concentration and buffer addition on duodenal flow of trans-C18:1 fatty acids and milk fat production in dairy cows. J. Dairy Sci. 80:2104-2114.

Karkalas, J. 1985. An improved enzymatic method for the determination of native and modified starch. J. Sci. Food Agric. 36:10191027.

Leek, B. F. 2004. Digestion in the ruminant stomach. Pages 438-474 in Dukes' Physiology of Domestic Animals. 12th ed. W. O. Reece. ed. Cornell University Press, Ithaca, NY.

Leek, B. F., and R. H. Harding. 1975. Sensory nervous receptors in the ruminant stomach and the reflex control of reticulo-ruminal motility. Pages 60-75 in Digestion and Metabolism in the Ruminant. Proc. 4th Int. Symp. Rumin. Physiol. I. W. McDonald and A. C. I. Warner, ed. The University of New England Publishing Unit, Armidale, Australia.

Maekawa, M., K. A. Beauchemin, and D. A. Christensen. 2002. Effect of concentrate level and feeding management on chewing activities, saliva production, and ruminal $\mathrm{pH}$ of lactating dairy cows. J. Dairy Sci. 85:1165-1175.

NRC. 2001. Nutrient Requirements of Dairy Cattle, 7th rev. ed. Natl. Acad. Press, Washington, DC.

Staples, C. R., and D. S. Lough. 1989. Efficacy of supplement dietary neutralizing agents for lactating dairy cows: A review. Anim. Feed Sci. Technol. 23:277-303.

Tyrrell, H. F., and J. T. Reid. 1965. Prediction of the energy value of cow's milk. J. Dairy Sci. 48:1215-1223.

Van Soest, P. J., J. B. Robertson, and B. A. Lewis. 1991. Methods for dietary fiber, neutral detergent fiber and nonstarch polysaccharides in relation to animal nutrition. J. Dairy Sci. 74:35833597.

Weast, R. C., ed. 1978. CRC Handbook of Chemistry and Physics. CRC Press Inc., Boca Raton, FL.

Welch, J. G. 1982. Rumination, particle size and passage from the rumen. J. Anim. Sci. 54:885-894.

Wildman, E. E., G. M. Jones, P. E. Wagner, R. L. Boman, H. F. Troutt Jr., and T. N. Lesch. 1982. A dairy cow body condition scoring system and its relationship to selected production characteristics. J. Dairy Sci. 65:495-501. 